
ARTHRITIS - A SHEAR WAVE ELASTOGRAPHY STUDY

Abdulrahman M. Alfuraih ${ }^{1,2,3}$, Ai Lyn Tan ${ }^{2,3}$, Philip O'connor ${ }^{3}$, Paul Emery ${ }^{2,3}$, Richard Wakefield ${ }^{2,3} .{ }^{1}$ Prince Sattam Bin Abdulaziz University, Radiology and Medical Imaging, Khari, Riyadh, Saudi Arabia; ${ }^{2}$ University of Leeds, Leeds Institute of Rheumatic and Musculoskeletal Medicine, Leeds, United Kingdom; ${ }^{3}$ Leeds Teaching Hospitals NHS Trust, Leeds Biomedical Research Centre, Leeds, United Kingdom

Background: Myopathy is a recognised but less investigated symptom of rheumatoid arthritis (RA) compared to other extra-articular manifestations. To date, the documentation of myopathic features in RA is poorly detailed. No studies have yet utilised a non-invasive quantitative method to define and investigate these features. Shear wave elastography (SWE), a novel ultrasound technology, can measure muscle stiffness to provide insight into the biomechanical properties of skeletal muscle.

Objectives: 1- To investigate muscle stiffness (using SWE) and strength in three cohorts of RA patients compared to healthy controls.

2- To study the association between muscle strength and stiffness in RA Methods: Shear wave velocity (SWV), as a measure of muscle stiffness, was evaluated in the quadriceps, hamstrings and biceps brachii in 80 RA patients from three disease activity groups newly diagnosed treatment naïve RA [ $n=29$; mean age $56.8 \pm 10.6$ years], persistent active RA for at least 1 year $[n=18 ; 60.9 \pm 15.9$ years] and remission RA for at least 1 year $[n=33 ; 65.9 \pm 11.6$ years], and compared them to 40 healthy controls $(56.8 \pm 10.6$ years). The participants performed various muscle tests (handgrip strength, expanded timed get up and walk test (ETGUG), chair stand and isokinetic knee extension/flexion) to assess their strength and physical performance. One-way ANOVA was used to compare SWV and muscle assessment results, and Pearson's correlation was used to evaluate the correlation between muscle stiffness and strength.

Results: Mean SWV was not significantly different amongst the RA groups or compared to the healthy controls $(p>0.05)$. For example, the rectus femoris SWV was $1.69 \pm 0.15 \mathrm{~m} / \mathrm{s}$ for healthy controls, $1.68 \pm 0.18$ $\mathrm{m} / \mathrm{s}$ for new RA, $1.70 \pm 0.16 \mathrm{~m} / \mathrm{s}$ for active RA and $1.68 \pm 0.14 \mathrm{~m} / \mathrm{s}$ for remission RA $(\mathrm{p}=0.96)$. The muscle assessment results are presented in table 1 and compared to healthy controls in figure 1. Overall, the active and new RA groups showed significant muscle weakness compared to healthy controls. The remission RA group did not show a significant difference except in the isokinetic knee strength $(-21 \% ; p=0.027)$. The correlations between SWE and the muscle assessment results were weak and insignificant $(r<0.30 ; p>0.05)$.

Table 1. Muscle assessment results for all participants

\begin{tabular}{|c|c|c|c|c|c|c|}
\hline Test & $\begin{array}{l}\text { Healthy } \\
\text { controls (a) }\end{array}$ & $\begin{array}{l}\text { New } \\
\text { RA (b) }\end{array}$ & $\begin{array}{l}\text { Active } \\
\text { RA (c) }\end{array}$ & $\begin{array}{l}\text { Remission } \\
\text { RA (d) }\end{array}$ & $\begin{array}{c}\mathrm{p}- \\
\text { value }\end{array}$ & $\begin{array}{l}\text { Post } \\
\text { hoc }^{*}\end{array}$ \\
\hline $\begin{array}{l}\text { ETGUGT, Total time } \\
\text { (sec) }\end{array}$ & $16.6(4.3)$ & $\begin{array}{l}20.7 \\
(5.7)\end{array}$ & $\begin{array}{l}21.5 \\
(6.3)\end{array}$ & $18.2(4.5)$ & 0.002 & $a>b, c$ \\
\hline $\begin{array}{l}\text { Number of chair } \\
\text { stands in } 30 \mathrm{sec}\end{array}$ & $17.0(5.8)$ & $\begin{array}{l}12.3 \\
(6.0)\end{array}$ & $9.5(6.3)$ & $14.0(5.4)$ & $<0.001$ & $a>b, c$ \\
\hline $\begin{array}{l}\text { Handgrip strength } \\
\text { (kg) }\end{array}$ & $31.5(13.7)$ & $\begin{array}{l}17.3 \\
(8.1)\end{array}$ & $\begin{array}{l}17.3 \\
(8.4)\end{array}$ & $26.6(10.9)$ & $<0.001$ & $\begin{array}{l}a, d>b \\
c\end{array}$ \\
\hline $\begin{array}{l}\text { Knee extension } \\
\text { torque }(\mathrm{Nm} / \mathrm{kg})\end{array}$ & $1.29(0.42)$ & $\begin{array}{l}1.06 \\
(0.45)\end{array}$ & $\begin{array}{c}0.93 \\
(0.47)\end{array}$ & $1.20(0.40)$ & 0.026 & $a>c$ \\
\hline $\begin{array}{l}\text { Knee flexion torque } \\
(\mathrm{Nm} / \mathrm{kg})\end{array}$ & $0.75(0.27)$ & $\begin{array}{l}0.53 \\
(0.27)\end{array}$ & $\begin{array}{l}0.60 \\
(0.29)\end{array}$ & $0.59(0.25)$ & 0.006 & $a>b, c$ \\
\hline $\begin{array}{l}\text { Knee extension } \\
\text { power }(W / k g)\end{array}$ & $0.75(0.29)$ & $\begin{array}{c}0.58 \\
(0.30)\end{array}$ & $\begin{array}{c}0.52 \\
(0.32)\end{array}$ & $0.68(0.28)$ & 0.029 & $a>c$ \\
\hline $\begin{array}{l}\text { Knee flexion power } \\
\text { (W/kg) }\end{array}$ & $0.47(0.18)$ & $\begin{array}{c}0.32 \\
(0.19)\end{array}$ & $\begin{array}{l}0.34 \\
(0.21)\end{array}$ & $0.34(0.18)$ & 0.005 & $a>b, c$ \\
\hline
\end{tabular}

* The signs $>$ or < indicate that the group(s) are significantly higher or lower at 0.05 * The signs $>$ or $<$ indicate that the group
significance level compared to others.

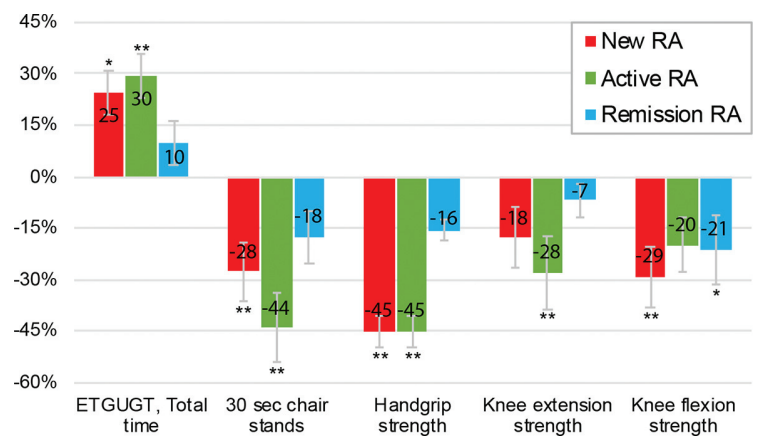

Figure 1. The difference percentages in muscle assessment results for the RA patients relative to the healthy controls.

Conclusion: Muscle stiffness, as determined using SWE, does not appear to be altered or associated with muscle weakness in RA patients. The remission RA group showed significantly better strength and physical performance compared to new untreated or persistently active RA groups. Future research should investigate the significant muscle weakness in RA in addition to developing prevention and therapeutic strategies.

Disclosure of Interests: Abdulrahman M. Alfuraih: None declared, Ai Lyn Tan: None declared, Philip O'Connor: None declared, Paul Emery Grant research support from: Pfizer, MSD, AbbVie, Bristol-Myers Squibb, Roche, Consultant for: Pfizer, MSD, AbbVie, Bristol-Myers Squibb, UCB, Roche, Novartis, Gilead,Samsung, Sandoz and Lilly, Richard Wakefield: None declared

DOI: 10.1136/annrheumdis-2019-eular.1214

\section{FRI0632 ASSOCIATION BETWEEN ULTRASOUND DIAGNOSIS AND ANALYTICAL AND SEROLOGICAL DATA IN PATIENTS WITH SUSPECTED PRIMARY SJÖGREN SYNDROME}

Laura Barrio Nogal, Cristina Bohórquez, Lucía Ruiz, Adrián Abbasi, Ana Pérez Gómez, Atusa Movasat, Ana Sánchez Atrio, Fernando Albarrán, Eduardo Cuende, Paula Pretel, Valentina Emperiale, Melchor Álvarez de Mon. Hospital Universitario Príncipe de Asturias, Madrid, Spain

Background: Pathophysiology of primary Sjögren syndrome (SSp) is characterized by oligoclonal B-cell proliferation and ectopic lymphoid tissue formation. The association between ultrasound glandular parenchyma heterogeneity and hyperproduction of autoantibodies, which in turn represents characteristic B-cell hyperactivity of $\mathrm{SSp}$, is described.

Objectives: To study the association between major salivary gland ultrasound (MSGUS) and their respective pathological grades with the analytical and serological data, and activity indexes obtained in patients with suspected SSp.

Methods: 72 patients were recruited consecutively with clinical and/or analytical suspicion of SSp from the Rheumatology outpatient consultations at the Príncipe de Asturias Hospital (2015-2018). Demographic, serological and validated activity indexes, ESSPRI and ESDAI, were collected. All of them underwent a MSGUS and their results were classified in three grades according to the Cornec et al system: normal (grade 0 and 1), mild (grade 2) and moderate-severe (grades 3 and 4). The final SSp diagnosis was made using both 2002 AECG and 2016 ACR/EULAR classification criteria. Data were analyzed using the software STATA. Association between MSGUS and qualitative variables was described according to the number of cases and the percentage by grades of MSGUS; the significance of the associations was tested with the Chi square test. As for the quantitative variables, the association was described with median and interval interquartile (IIQ) by grades of MSGUS and the significance of the association was verified with the non-parametric test of Kruskall-Wallis.

Results: From patients with pathological MSGUS: $51 \%$ had antiRo52, $51 \%$ antiRo60 and $36 \%$ anti-La positive; $62 \%$ hypergammaglobulinemia, $40 \%$ positive rheumatoid factor (RF), $6 \%$ and $13 \%$ C3 and C4 hypocomplementemia, respectively. Mean values were obtained: ESR 36, CRP 1.6, RF 12, ESSPRI 5.6 and ESSDAI 2. Statistically significant differences $(p<0.05)$ were only found in antiRo52 and hypergammaglobulinemia variables in patients with normal MSGUS exam compared to those with 